\title{
The pathogenetic role of $\beta$-cell mitochondria in type 2 diabetes
}

\author{
Malin Fex', Lisa M Nicholas', Neelanjan Vishnu', Anya Medina', Vladimir V Sharoyko', David G Nicholls', \\ Peter Spégel ${ }^{1,2}$ and Hindrik Mulder ${ }^{1}$
}

'Department of Clinical Sciences in Malmö, Unit of Molecular Metabolism, Lund University Diabetes Centre, Clinical Research Center, Malmö University Hospital, Lund University, Malmö, Sweden

2Department of Chemistry, Center for Analysis and Synthesis, Lund University, Sweden

Correspondence should be addressed to H Mulder: hindrik.mulder@med.lu.se

\begin{abstract}
Mitochondrial metabolism is a major determinant of insulin secretion from pancreatic $\beta$-cells. Type 2 diabetes evolves when $\beta$-cells fail to release appropriate amounts of insulin in response to glucose. This results in hyperglycemia and metabolic dysregulation. Evidence has recently been mounting that mitochondrial dysfunction plays an important role in these processes. Monogenic dysfunction of mitochondria is a rare condition but causes a type 2 diabetes-like syndrome owing to $\beta$-cell failure. Here, we describe novel advances in research on mitochondrial dysfunction in the $\beta$-cell in type 2 diabetes, with a focus on human studies. Relevant studies in animal and cell models of the disease are described. Transcriptional and translational regulation in mitochondria are particularly emphasized. The role of metabolic enzymes and pathways and their impact on $\beta$-cell function in type 2 diabetes pathophysiology are discussed. The role of genetic variation in mitochondrial function leading to type 2 diabetes is highlighted. We argue that alterations in mitochondria may be a culprit in the pathogenetic processes culminating in type 2 diabetes.
\end{abstract}

Journal of Endocrinology (2018) 236, R145-R159

\section{Introduction}

Seminal work in the 1960s and 1970s established that insulin secretion is deficient in type 2 diabetes (T2D) (Bagdade et al. 1967, Simpson et al. 1968). In the last decade, a number of genome-wide association studies (GWAS) of patients with T2D and metabolic traits have been published (Saxena et al. 2007, Scott et al. 2007, Sladek et al. 2007, Zeggini et al. 2007, Gaulton et al. 2015, Fuchsberger et al. 2016). The number of gene loci conferring increased risk for T2D that have been identified now surpasses one hundred. Those genes, which are most strongly associated with $\mathrm{T} 2 \mathrm{D}$, all seem highly relevant for $\beta$-cell function and development (Prasad \& Groop 2015). Therefore, there is currently very strong evidence to support the notion that failure of insulin secretion is the defining event in the pathogenesis of T2D (Kasuga 2006, Muoio \& Newgard 2008, Ashcroft \& Rorsman 2012, Prasad \& Groop 2015).

Accordingly, this breakthrough has changed the focus of much of the research on the pathogenesis of T2D. It has prompted research on genomic processes, e.g., genetic polymorphisms, epigenetic mechanisms, micro and linker RNAs and chromatin structure, which are robustly linked to the disease and centering on the pancreatic $\beta$-cell. This notwithstanding, information about how functional and structural abnormalities, resulting from genomic alterations in islets, lead to the perturbation of insulin 
secretion, which underlies the disease in humans, is still scant for most candidate genes described thus far ( $\mathrm{Ng} \&$ Gloyn 2013).

Whether deficient $\beta$-cell mass plays a pathogenetic role in T2D has been debated for decades (Ahrén 2005). Available data suggest that there is loss of $\beta$-cell mass in T2D due to increased apoptosis (Butler et al. 2003). However, such reduction cannot by itself account for the impairment of insulin secretion in T2D; $\beta$-cell loss in obese and lean individuals is $\sim 60$ and $40 \%$, respectively, compared with obese and lean non-diabetic individuals (Butler et al. 2003). Thus, a functional defect is still required, in addition to the observed loss of $\beta$-cell mass, for insulin secretion to be impaired.

There is consensus that insulin secretion is mainly controlled by metabolism of fuels, foremost glucose, in the pancreatic $\beta$-cell (Muoio \& Newgard 2008, Ashcroft \& Rorsman 2012, Wiederkehr \& Wollheim 2012). Stimulation by glucose, and hence $\beta$-cell metabolism, is required for effective control of insulin secretion by circulating hormones, paracrine and autocrine mechanisms and neuronal (autonomic and sensory) activity. All these mechanisms combine to enhance insulin secretion in an efficacious fashion (Ahrén 2000). Here, mitochondria play a key role (Wollheim 2000 Mulder \& Ling 2009, Nicholls 2016); oxidation of most cellular fuels produces reducing equivalents, driving the electron transport chain and subsequently ATP production via oxidative phosphorylation (OXPHOS). A rise in ATP:ADP ratio closes the ATP-sensitive $\mathrm{K}^{+}$channel $\left(\mathrm{K}_{\text {ATP }}\right)$, depolarizes the plasma membrane, opens voltage-gated $\mathrm{Ca}^{2+}$ channels and subsequently triggers exocytosis of insulincontaining granules. This pathway is also known as the $\mathrm{K}_{\mathrm{ATP}}$-dependent or triggering pathway (Henquin 2000). In addition, mitochondria play an essential role in the $\mathrm{K}_{\mathrm{ATP}}{ }^{-}$ independent or amplifying pathway of insulin secretion (Maechler et al. 2006). Metabolites from mitochondria, reducing equivalents or metabolite fluxes, account for the sustained phase of insulin secretion (Prentki \& Corkey 1996), which cannot be upheld by raised intracellular $\mathrm{Ca}^{2+}$ alone (Jonas et al. 1994), i.e., the result of the triggering pathway. Mitochondria hereby play an essential role in the control of insulin secretion, the deciding pathogenetic event in T2D.

Mitochondria also serve a critical role in control of $\beta$-cell mass. Available data suggest that increased apoptosis underlies the loss of $\beta$-cell mass observed in islets from patients with T2D (Butler et al. 2003). In fact, a loss of $\beta$-cell mass by $64 \%$ in pancreatectomized patients is associated with diabetes (Meier et al. 2012). Apoptotic pathways converge in mitochondria, where a cascade of caspase activation by cytochrome $\mathrm{C}$, after being exported from mitochondria, is required for triggering of apoptosis. Interestingly, reduction of cytochrome C levels and translocation have also been proposed as coupling signals in glucose-stimulated insulin secretion (GSIS) (Jung et al. 2011). Ageing is another component of the pathogenesis of T2D, again implicating mitochondrial metabolism in $\beta$-cell dysfunction (Ling et al. 2004, Lee et al. 2007, Ling et al. 2007, Trifunovic \& Larsson 2008). For all these reasons, mitochondria are main players in the pathogenesis of T2D. Here, we will describe the role of mitochondria in $\beta$-cells during the events leading to T2D. We will focus on human studies, but where relevant, also include observations from experimental in vitro and in vivo models.

\section{The consensus model of fuel-stimulated insulin secretion}

The manner by which glucose and other fuels control insulin secretion has been extensively reviewed elsewhere (Ashcroft \& Rorsman 2012, Wiederkehr \& Wollheim 2012, Mulder 2017). Thus, only some of the main aspects will be summarized here for context, as well as some recent work, performed by us, to deepen the understanding of how mitochondria and glycolysis co-operate to control insulin release and how oscillations in metabolism may contribute to this (Fig. 1).

\section{Coupling of mitochondrial and glycolytic metabolism in pancreatic $\beta$-cells}

Glucose taken up by the $\beta$-cell is rapidly phosphorylated by the low-affinity enzyme glucokinase (GCK). Loss-offunction mutations in GCK cause a monogenic form of diabetes (maturity onset diabetes of the young 2; MODY2) that result in a right-shift in the dose-response curves of glucose and insulin secretion; however, this does not result in progressive $\beta$-cell dysfunction and hyperglycemia does not increase over time (Fajans et al. 2001). On the contrary, activating (gain-of-function) mutations in GCK cause familial hyperinsulinism (Glaser et al. 1998). The end product of glycolysis, the triose pyruvate, is then destined for mitochondrial aerobic metabolism as expression of lactate dehydrogenase A (LDHA) is low in the $\beta$-cell; it is in fact considered a 'disallowed/forbidden $\beta$-cell gene' (Pullen et al. 2010, Thorrez et al. 2011). To compensate for the lack of $\mathrm{LDH}$, the $\beta$-cell is equipped 


\begin{tabular}{l|l|l|c|c|} 
Journal of & M Fex et al. & Mitochondria in $\beta$-cells & $\mathbf{2 3 6 : 3}$ \\
Endocrinology & & R147
\end{tabular}

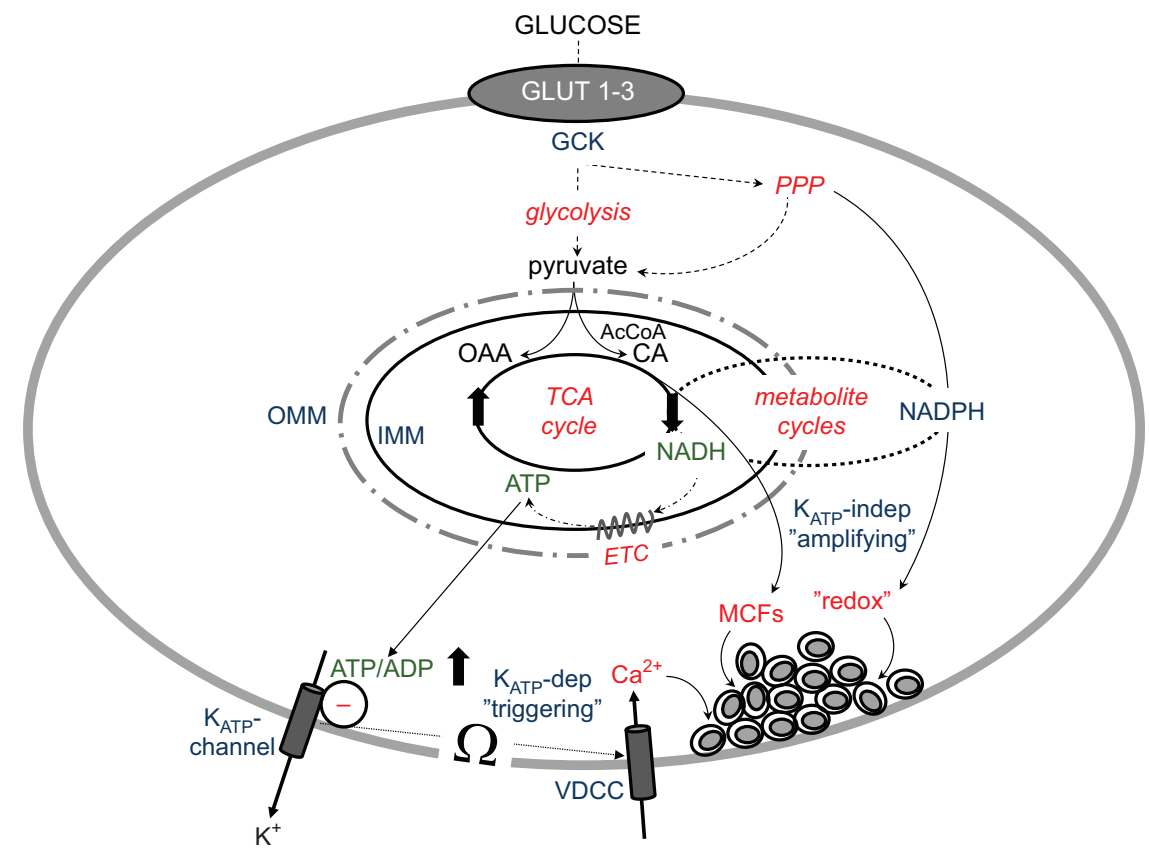

\begin{abstract}
Figure 1
Stimulus-secretion coupling in the pancreatic $\beta$-cell. Glucose is taken up into the $\beta$-cell in a process termed facilitated diffusion; this occurs in proportion to the extracellular concentration of the hexose. Next, glucose is phosphorylated by glucokinase (GCK), a rate-limiting step in glucose metabolism, followed by glycolysis and further metabolism in the tricarboxylic acid (TCA) cycle, resulting in a rise in the ATP/ADP ratio. This closes an ATP-dependent $\mathrm{K}^{+}$channel $\left(\mathrm{K}_{\mathrm{ATP}}\right)$ in the plasma membrane. As a consequence, voltage-dependent $\mathrm{Ca}^{2+}$ channels (VDCC) open and the intracellular surge of $\mathrm{Ca}^{2+}$ triggers exocytosis of the hormone. Metabolic coupling factors (MCF) cannot induce insulin secretion by themselves but are thought to amplify insulin secretion. They are supposedly generated by metabolite cycles, which are associated with the TCA cycle, as well as the pentose phosphate pathway (PPP). Examples of MCFs are NADPH, mediating its effect via cellular redox, glutamate or lipid moieties. AcCoa, acetyl-COA; CA, citrate; ETC, electron transport chain; GLUT, glucose transporters; IMM, inner mitochondrial membrane; OAA, oxaloacetate; OMM, outer mitochondrial membrane; $\Omega$, membrane polarization.
\end{abstract}

with both the malate-aspartate shuttle and the glycerolphosphate shuttle (Eto et al. 1999). Thereby, replenishment of cytosolic $\mathrm{NAD}^{+}$is efficiently accomplished and mitochondrial glucose oxidation maximized. Hence, glycolysis in the $\beta$-cell is designed to shuttle glucose, via pyruvate, to the mitochondria, to fuel ATP production. This is further supported by the fact that more than $80 \%$ of supplied glucose is completely oxidized to $\mathrm{CO}_{2}$ and water in the $\beta$-cell (Schuit et al. 1997). The importance of glucose-dependent pyruvate supply to the mitochondria is further underscored by the fact that reduced expression of GLUT2 is associated with lower glucose oxidation in islets from donors with T2D (Del Guerra et al. 2005). On the contrary, expression of the monocarboxylate transporter 1, another 'disallowed $\beta$-cell gene' (Pullen et al. 2010, Thorrez et al. 2011), in the $\beta$-cell results in exercise-induced hypoglycemia, as pyruvate released from exercised muscle activates mitochondrial metabolism, resulting in hyperinsulinism (Otonkoski et al. 2007).

Hence, glycolytic metabolism is tightly coupled to mitochondrial metabolism. We showed that glucose responsiveness in INS-1-derived clonal cell lines is tightly linked to expression of $L D H A$ and that expression of this 'disallowed $\beta$-cell gene' in human islets correlates positively with HbA1c levels (Malmgren et al. 2009). In a follow-up study, we demonstrated that this circumstance is likely linked to increased stabilization of hypoxia-inducible factor $1 \alpha$, targets of which exhibit increased expression in islets from donors with T2D (Spégel et al. 2014).

In addition to production of ATP - the main trigger of insulin secretion - multiple coupling factors, mainly emanating from mitochondrial metabolism, have been suggested to amplify secretion of the hormone (Wiederkehr \& Wollheim 2012, Mulder 2017). Although the significance of many of these factors has been questioned, studies of them have clearly shown that mitochondrial enzymes catalyzing production of putative coupling factors are essential for a robust GSIS. One of the most extensively studied coupling factors is glutamate (Maechler \& Wollheim 1999), which also is an important component of the malate-aspartate shuttle. Indeed, activating mutations in the gene encoding glutamate dehydrogenase, result in increased flux from glutamate to the TCA cycle intermediate $\alpha$-ketoglutarate, likely underlying hyperinsulinism (Stanley et al. 1998). However, there are also reports refuting the role of glutamate as a metabolic coupling factor (Bertrand et al. 2002).

Although the majority of publications highlights the mitochondria as the source of factors that trigger and amplify secretion of insulin, studies have also implicated purely cytosolic processes in $\beta$-cell stimulus-secretion coupling. To exemplify, we reported that the pentose phosphate pathway is highly active in rodent-derived insulin-secreting cells and that inhibition of this pathway 
perturbs GSIS from islets (Spégel et al. 2013). This pathway may signal to insulin secretion from human $\beta$-cells via formation of NADPH and altered redox potential (Ivarsson et al. 2005), but potentially also via production of adenylosuccinate, as was recently suggested (Gooding et al. 2015). Clearly, GSIS is a complex process, which is influenced by multiple metabolic pathways. Mitochondrial metabolism is indispensable in this machinery, but relies on a close interplay with cytosolic metabolic events. There has been a tendency for metabolic and electrophysiological investigations of $\beta$-cells to proceed along parallel tracks with limited interaction. Thus, the crucial importance of plasma membrane potential oscillations, central to the electrophysiology of the intact islet and the control of insulin secretion, may have been overlooked in metabolic investigations.

Transient opening of voltage-activated $\mathrm{Ca}^{2+}$ channels (Goehring et al. 2012) and exocytosis (Gerencser et al. 2015) are tightly coupled to depolarizing spikes in the plasma membrane potential. While 'Spiking' requires inhibition of $\mathrm{K}_{\mathrm{ATP}}$-channels by mitochondrial bioenergetics, no associated oscillations in ATP levels or mitochondrial membrane potential were detected (Goehring et al. 2012). Glycolytic oscillation could also be eliminated, since exogenous provision of pyruvate fully supports plasma membrane potential oscillations. A critical, but poorly understood, determinant of GSIS, at least in INS-1 832/13 cells, would appear to be the factor that controls spike frequency and amplitude.

\section{Changes in mitochondrial metabolism in type 2 diabetes}

\section{Mitochondrial metabolism in $\beta$-cells of insulin-resistant mice}

At this point, there is little information on how mitochondria in human $\beta$-cells adapt when an individual becomes insulin resistant. In contrast, there are data available on how hyperinsulinemia evolves as a compensatory process to account for insulin resistance in skeletal muscle and adipose tissue (Abdul-Ghani et al. 2006). Concurrently, the remarkable plasticity of the mitochondria as an organelle has become increasingly appreciated (Detmer \& Chan 2007). Mitochondria alter shape and volume in response to changes in cellular function and demands, a plasticity which serves to optimize mitochondrial function and metabolism for every specific situation.
A number of mouse models have been used to study mitochondrial dysfunction in metabolic diseases (Supale et al. 2012). To study $\beta$-cell mitochondrial metabolism in insulin resistance, we fed C57BL/6J mice a high-fat diet. These mice become severely insulin resistant but do not develop frank diabetes (Ahrén et al. 1997), thus allowing studies of the normal processes in pancreatic $\beta$-cells that strive to adapt to the diabetogenic metabolic perturbations associated with reduced insulin sensitivity. High-fat diet-fed C57BL/6J mice exhibit basal hyperinsulinemia but retarded glucose disposal. Ex vivo, GSIS is blunted, while responses to fuels directly mediating their effects via mitochondrial metabolism are exaggerated (Fex et al. 2007a). This metabolic switch from glucose to other mitochondrial fuels parallels enhanced oxidation of palmitate and glutamine in the face of reduced glucose oxidation. The dissociation of effects provoked by glucose and mitochondrial fuels is associated with perturbed GLUT2 localization, suggesting a disruption of glucose metabolism and confirming previous findings (Reimer \& Ahrén 2002). The number of mitochondria is unchanged, while mass is increased by $\sim 60 \%$ (Fex et al. 2007a). Exaggerated deposition of neutral lipids suggests altered lipid flux. Despite these marked metabolic changes, alterations in gene expression of transcription factors and co-activators involved in mitochondrial biogenesis and control of metabolic enzymes and respiratory chain proteins are largely absent; this includes peroxisome proliferator-activated receptor $\gamma$ coactivator $1 \alpha$ (PGC- $1 \alpha)$, PGC-1 $\beta$, nuclear respiratory factor- 1 and mitochondrial transcription factor A (TFAM). Expression levels of the nuclear-encoded mitochondrial protein cytochrome C and the mitochondria-encoded mitochondrial protein cytochrome c oxidase IV (COXIV) remain unaltered during or after 12 weeks of high-fat feeding (Fex et al. 2007a).

\section{Mitochondrial bioenergetics in glucotoxicity}

Another main pathogenetic paradigm in $\mathrm{T} 2 \mathrm{D}$ is the adverse effects of hyperglycemia, termed glucotoxicity. A plethorum of studies has addressed it and will not be reviewed here for the sake of space (Poitout et al. 2010). We have used INS-1 832/13 cells to understand mitochondrial bioenergetics in glucotoxicity; these cells respond to chronic incubation under hyperglycemic conditions $(16.7 \mathrm{mM}$ glucose for $48 \mathrm{~h}$, followed by $2 \mathrm{~h}$ recovery in $2.8 \mathrm{mM}$ glucose) with decreased responsiveness, relative to cells cultured in $2.8 \mathrm{mM}$ glucose, to acute glucose or exogenous pyruvate with respect to mitochondrial 
inner membrane hyperpolarization, plasma membrane depolarization and insulin secretion (Goehring et al. 2012, 2014, Gerencser et al. 2015). 'Bioenergetic overload' or chronic provision of saturating mitochondrial substrate could be eliminated, since cells cultured in low glucose plus pyruvate show no deficit, and do not retain elevated levels of glycolytic or mitochondrial substrates after the 2-h preincubation. Indeed, the 'high glucose' cells display enhanced glycolysis and respiration. We concluded that extra-mitochondrial metabolism upstream of pyruvate, rather than excess mitochondrial substrate provision, underlies glucotoxicity in these insulin-secreting cells (Goehring et al. 2012, 2014, Gerencser et al. 2015).

\section{Mitochondrial dysfunction in C57BL/6J mice}

A strain of C57BL/6J mice exhibits impaired glucose disposal on a normal diet, which could be attributed to impaired insulin secretion (Toye et al. 2005). The glucose-unresponsive islets exhibit a normal rise in intracellular $\mathrm{Ca}^{2+}$ when stimulated by tolbutamide, and $\mathrm{K}_{\mathrm{ATP}}$-channels close in response to ATP. Collectively, these findings point towards a metabolic defect in pancreatic $\beta$-cells. Indeed, this strain was found to harbour a 5-exon deletion in the nicotinamide nucleotide transhydrogenase (Nnt) gene. This enzyme catalyzes the reversible conversion of $\mathrm{NADP}^{+}$and $\mathrm{NADH}$ into NADPH and $\mathrm{NAD}^{+}$. It is associated with the respiratory chain and has been suggested to protect mitochondria from an overload of reactive oxygen species (ROS), which could impair their function (Jonas et al. 2009). Glutathione reductase requires NADPH to reduce glutathione, a component of the detoxifying mechanism.

Recent studies in this substrain of C57BL/6J show that NNT is required for the acute glucose-induced rise in islet $\mathrm{NADPH} / \mathrm{NADP}^{+}$ratio, while decreasing the mitochondrial glutathione oxidation (Santos et al. 2017). This action depends on a reduction in NADPH consumption by NNT, which relies on glucose and appears to operate in reverse mode rather than from enhancing its forward mode of operation. Interestingly, the insulinotropic effect is accounted for by an enhancement of $\mathrm{Ca}^{2+}$-induced exocytosis rather than influx of $\mathrm{Ca}^{2+}$ and mitochondrial events.

Not all strains of C57BL/6J mice harbour the Nnt mutation. The 5-exon deletion is lacking from the C57BL/6N strain that we use (Fex et al. 2007b), which was derived from the one kept at the NIH Animal Genetic Resource, and embryo-derived into Taconic's facility; C57BL/6J mice are also available from the Jackson
Laboratory, and these were used in the studies on NNT (Toye et al. 2005).

\section{Mitochondrial changes in human $\beta$-cells in T2D}

Development of international centers for islet transplantation has allowed access to human islets for research purposes. As a consequence, there is now information about islet function and mitochondrial alterations in human T2D. Metabolites enhancing mitochondrial metabolism evoke insulin release from T2D islets (Fernandez-Alvarez et al. 1994), while GSIS is impaired. Moreover, GSIS, but not arginine- and glibenclamide-stimulated insulin release, is impaired in islets from patients with T2D (Del Guerra et al. 2005). Mitochondrial fuels were not tested. Islets, which were obtained from 14 cadaveric donors with T2D, are smaller and contain a reduced proportion of $\beta$-cells (Deng et al. 2004). In addition, GSIS is impaired while the maximal secretory response, elicited by $\mathrm{KCl}$, is unchanged (Deng et al. 2004). These results suggest that islets from donors with T2D have a specific metabolic impairment, since the secretory dysfunction is restricted to glucose stimulation.

Analyses of insulin secretion and mitochondrial function in islets from seven donors with T2D showed that glucose-stimulated, but not arginine-stimulated, insulin secretion is impaired (Anello et al. 2005), suggesting the existence of a specific metabolic impairment in $\beta$-cells in T2D. Basal ATP levels are elevated in T2D islets, and they fail to respond with a rise in the ATP:ADP ratio, an event known to trigger insulin secretion. Hyperpolarization of the inner mitochondrial membrane upon glucose stimulation is reduced in the diabetic islets. A moderate increase in uncoupling protein-2 (UCP-2) levels is evident, which could uncouple the respiratory chain from ATP production (Anello et al. 2005). Interestingly, changes in mitochondrial structure paralleled these functional alterations: there is no increase in mitochondrial number, but their volume is increased, a finding similar to that we reported in C57BL/6J mice on a high-fat diet (Fex et al. 2007a). Also, expression of complex I and V is increased in the islets from patients with T2D (Anello et al. 2005).

Reduced utilization (Fernandez-Alvarez et al. 1994) and oxidation (Lupi et al. 2004) of glucose also support that there is metabolic dysfunction in islets from T2D; there is increased oxidative stress (Del Guerra et al. 2005), as well as nitrotyrosine levels, in islets from donors with T2D (Anello et al. 2005). $\beta$-cells from patients with T2D and from non-diabetic donors possess similar numbers of mitochondria but the mitochondrial volume density is 
significantly higher in T2D (Anello et al. 2005). Activities of metabolic enzymes such as glycerol phosphate dehydrogenase, pyruvate carboxylase and succinylCoA:3-ketoacid-CoA transferase are reduced in islets from patients with T2D (MacDonald et al. 2009), as is expression of the FAD-linked glycerol phosphate dehydrogenase (Lupi et al. 2004), an enzyme-linking glycolysis with TCA cycle metabolism.

These data clearly point towards a role for mitochondria in the pathology of islets in T2D. Nevertheless, while some data support the role of UCP-2 in the pathogenesis of diabetes (Zhang et al. 2001), others have raised concerns about whether the protein is indeed an uncoupler (Nicholls 2006, Pi et al. 2009). It is unclear whether the modest increase of UCP-2 expression that was observed can account for such a profound effect on ATP production (Anello et al. 2005); clearly, much greater increases in UCP-2 expression were employed in experimental studies, where the protein was found to impair insulin secretion (Chan et al. 1999). Moreover, changes in metabolism were not analyzed, and such changes could also have exerted the observed effects on ATP production.

\section{Structural dynamics, biogenesis of mitochondria and mitophagy}

Mitochondrial structure and number are subject to plasticity (Mannella 2006, Detmer \& Chan 2007). Observations we have made in $\beta$-cells from insulinresistant mice (Fex et al. 2007a) and in mice where mitochondrial transcription factors have been targeted (Koeck et al. 2011), and others have made in human islets from donors with T2D (Anello et al. 2005) underscore the importance of flexibility in mitochondrial number and volume density. These events are highly regulated, providing the cell with organelles that are optimally functional in any given cellular state. The process by which mitochondria are formed is termed mitochondrial biogenesis. It is the result of a balance of fission and fusion of pre-existing mitochondria. In addition to these intermitochondrial alterations, changes within mitochondria are also observed (Mannella 2006). Fusion and fission of the inner mitochondrial membrane seem to be the critical events and are supposedly regulatory processes in the organelle; these structural changes may affect diffusion of protons as well as proteins (e.g., cytochrome C) and ATP production.

Removal of damaged mitochondria occurs via mitophagy, a process serving to clear cells of harmful and dysfunctional components (Fig. 2). Here, mitochondria are specifically targeted and selectively removed when damaged or dysfunctional. Mitophagy was first identified in mammalian cells by electron microscopy that identified mitochondrial sequestration in lysosomal compartments following stimulation of hepatocytes with glucagon (De Duve \& Wattiaux 1966). Based on this model, and a starvation model, the term mitophagy was coined to describe the engulfment of mitochondria into double-membrane vesicles coated with the autophagy marker LC3 (Kim et al. 2007). Indeed, activation of resident mitochondrial proteins that contain LC3-interacting regions is thought to attract autophagosomes to dysfunctional mitochondria. FUNDC1 and the BH3-only family protein BNIP and NIX are such proteins; they are implicated in mitophagy induced by hypoxia and metabolic stress (Zhang \& Ney 2009, Liu et al. 2012). Additional proteins known to play a major role in mediating mitophagy are PINK1 and Parkin (Park2); they

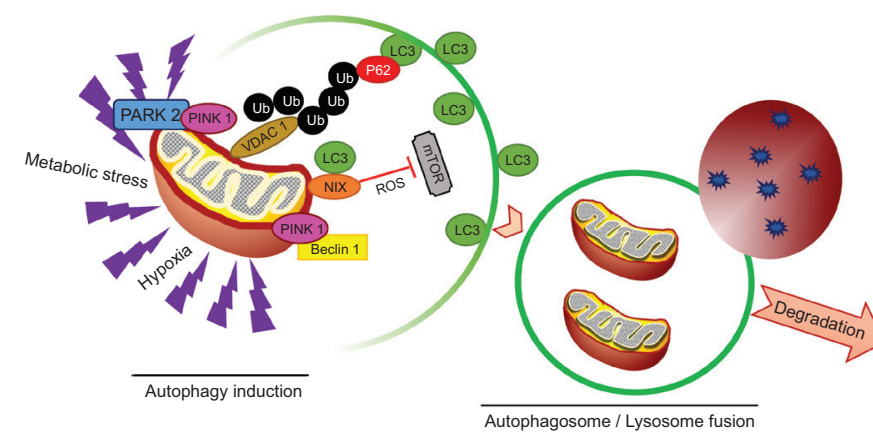

http://joe.endocrinology-journals.org https://doi.org/10.1530/JOE-17-0367 (c) 2018 Society for Endocrinology Published by Bioscientifica Ltd. Printed in Great Britain

\section{Figure 2}

Mitophagy in $\beta$-cells. Mitophagy is an autophagic process, whereby dysfunctional mitochondria are eliminated and cellular material reutilized. Mitochondria are thus engulfed into doublemembrane vesicles coated with the autophagy marker LC3, which attract autophagosomes to dysfunctional mitochondria. PINK1 and Parkin (Park2) play a major role in mediating mitophagy, as they are involved in processes upstream of autophagosome formation. Ubiquitination (Ub) is key to salvage proteins into amino acids in the proteasome, which may refuel cellular metabolism. Also, pathways controlled by the mammalian target of rapamycin (mTOR), including formation of reactive oxygen species (ROS), play a decisive role in the processes culminating in mitophagy. 
are both involved in processes upstream of autophagosome formation and are also expressed in $\beta$-cells (Jin \& Youle 2012). Interestingly, expression of PDX1, a $\beta$-cell masterregulator, was recently implicated in control of mitophagy in $\beta$-cells (Soleimanpour et al. 2015). Indeed, we observed reduced expression of PDX1 in $\beta$-cells from mice lacking transcription factor B2 mitochondrial (TFB2M), where both mitophagy and autophagy were evident (Nicholas et al. 2017).

The heterogeneity and subsequent plasticity of mitochondria in $\beta$-cells have also recently been demonstrated functionally. Under normal condition, exposure to glucose leads to hyperpolarization of the inner mitochondrial membrane. However, it has been shown that a subpopulation of mitochondria exhibits a lower level of polarization - these mitochondria may even become depolarized (Wikström et al. 2007). Glucose and methyl-succinate, a mitochondrial fuel, recruit mitochondria from this pool into a hyperpolarized one. Under glucolipotoxic conditions, the proportion of mitochondria in the hyperpolarized population increases. This has been proposed as a potential mechanism for how glucolipotoxicity arises (Liesa \& Shirihai 2013). Moreover, depolarized mitochondria may be more amenable to mitophagy (Twig et al. 2008).
Mitofusin 1 and 2 are localized to the outer mitochondrial membrane, together with the optic atrophy 1 protein (OPA1), which is localized to the inner mitochondrial membrane. These proteins are the key regulators of mitochondrial fusion events (Cipolat et al. 2004, Frezza et al. 2006). The cytosolic dynamin-related protein 1 oligomerizes when mitochondrial fission occurs; it is recruited to the mitochondrion via an interaction with the outer membrane protein FIS1 (Lee et al. 2004, Zhang $\&$ Chan 2007). This causes constriction and severing of mitochondria. MtDNA copy number in $\beta$-cells lacking Opa1 is unchanged, but the activity of complex IV is significantly decreased, perturbing glucose-stimulated ATP production and GSIS (Zhang et al. 2011). It was found that glucose-unresponsive cells exhibit poorer mitochondrial dynamics than glucose-responsive cells (Schultz et al. 2016). Overexpression of FIS1 in glucose-unresponsive cells restores GSIS, and the mitochondrial network becomes more homogeneous. In contrast, silencing of Fis1 in murine insulin-secreting cells lessens glucose responsiveness and a higher frequency of elongated, likely dysfunctional, mitochondria is encountered (Schultz et al. 2016). The prohibitin proteins have also been suggested to play important roles in maintaining mitochondrial integrity and function. Indeed, targeting Phb2 in mouse

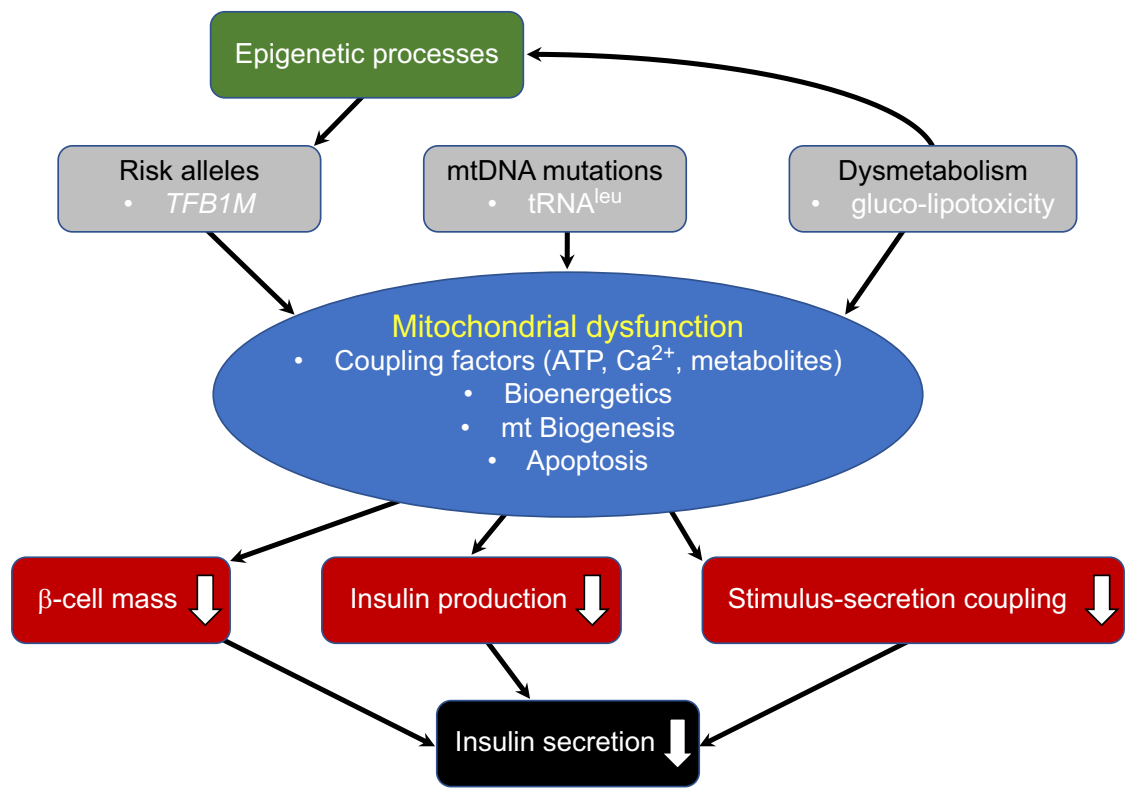

Figure 3

Mechanisms of $\beta$-cell mitochondrial dysfunction in type 2 diabetes (T2D). Mitochondrial dysfunction in pancreatic $\beta$-cells leading to impaired insulin secretion and T2D may be accounted for by several processes, alone or in combination. A number of mutations in mitochondrial DNA (mtDNA) cause dysfunction of mitochondria in pancreatic $\beta$-cells; this is known as mitochondrial diabetes, which is distinct from T2D, since it has a distinct etiology. At least one of the identified risk alleles for T2D, i.e., TFB1M, which encodes a factor (transcription factor B1 mitochondrial, TFB1M) that is required for translation of proteins in mitochondria, has been implicated in mitochondrial dysfunction in T2D. Epigenetic processes, influenced by chronic metabolic changes, may interact with gene variants. More generally, metabolic abnormalities, e.g., elevations of circulating lipids and/or glucose, known as lipo- and glucotoxicity, have also been shown to impact negatively on mitochondrial function in $\beta$-cells. Mitochondrial dysfunction may negatively affect formation of coupling factors, dynamics of cellular $\mathrm{Ca}^{2+}$, and the rise in the ATP/ADP ratio, as well as bioenergetics and biogenesis and induce apoptosis. These processes will hamper production and release of insulin but may also lead to loss of $\beta$-cell mass. 
$\beta$-cells impairs mitochondrial function, leading to a loss of $\beta$-cell mass and GSIS (Supale et al. 2013); the deficits can be attributed to both loss of function and number of $\beta$-cells.

PGC- $1 \alpha$ appears to be a master switch in mitochondrial biogenesis via co-activation of many nuclear receptors and other factors (Handschin \& Spiegelman 2006). Its control is mainly exerted by activation of nuclear respiratory factor 1 and 2. TFAM and TFB2M are essential for transcription of the mitochondrial DNA (Ekstrand et al. 2004), a prerequisite for mitochondrial biogenesis. Interestingly, a conditional knock out of Tfam or $T f b 2 m$ in $\beta$-cells results in impaired fuel-stimulated insulin secretion and diabetes in mice (Silva et al. 2000, Nicholas et al. 2017).

\section{Genetic regulation of mitochondria and associations with T2D}

\section{The mitochondrial genome and diabetes}

Mitochondrial ATP production is a pre-requisite for fuel-stimulated insulin secretion (Henquin 2000, Wollheim 2000, Muoio \& Newgard 2008). OXPHOS and ATP production occur in a system consisting of five multiprotein complexes with 90 known protein subunits (Scarpulla 2008). The vast majority of these subunits is encoded by the nuclear genome, while 13 subunits are encoded by mitochondrial DNA (mtDNA; Table 1), a 16.6$\mathrm{kb}$ circular double-stranded DNA molecule. Depletion of mtDNA in $\beta$-cells results in perturbed mitochondrial metabolism and abrogated fuel-stimulated insulin secretion (Kennedy et al. 1996).

Heteroplasmy, i.e., the fact that cells contain multiple mitochondria, which may differ with respect to mtDNA sequence, may explain that work in this area is often contradictory. This notwithstanding, rare mutations in mtDNA in humans have been shown to cause mitochondrial dysfunction, and this may lead to diabetes due to $\beta$-cell dysfunction (Maassen et al. 2005). These mutations mostly target mitochondrial tRNA genes; for instance, a mutation of 3243 in tRNA ${ }^{\text {Leu }}$ causes the syndromes of maternally inherited diabetes and deafness and mitochondrial encephalopathy, lactacidosis and stroke (Maassen et al. 1996). It is also likely that a mutation in the sequence for tRNA Leu causes mitochondrial dysfunction via disrupted expression and/or function of other mitochondrial genes, owing to disturbed protein synthesis. Hybrid cells, containing mitochondria with mutated DNA, exhibit metabolic impairments that may lead to defective $\beta$-cell stimulus-secretion coupling
Table 1 The mitochondrial DNA encodes 13 mitochondrial proteins, which constitute critical parts of the electron transport chain.

\begin{tabular}{|c|c|c|c|}
\hline \multicolumn{4}{|c|}{ Mitochondrial genes encoding proteins } \\
\hline Gene name & Gene bank ID & Protein & Complex \\
\hline$M T-N D 1$ & 4535 & NADH dehydrogenase 1 & I \\
\hline$M T-N D 2$ & 4536 & NADH dehydrogenase 2 & I \\
\hline$M T-N D 3$ & 4537 & NADH dehydrogenase 3 & I \\
\hline$M T-N D 4$ & 4538 & NADH dehydrogenase 4 & I \\
\hline$M T-N D 4 L$ & 4539 & NADH 4L dehydrogenase & I \\
\hline MT-ND5 & 4540 & NADH dehydrogenase 5 & I \\
\hline$M T-N D 6$ & 4541 & NADH dehydrogenase 6 & I \\
\hline$M T-C Y B$ & 4519 & Cytochrome b & III \\
\hline MT-CO1 & 4512 & $\begin{array}{l}\text { Cytochrome c oxidase } \\
\text { I (COX1) }\end{array}$ & IV \\
\hline MT-CO2 & 4513 & $\begin{array}{l}\text { Cytochrome c oxidase II } \\
\text { (COX2) }\end{array}$ & IV \\
\hline MT-CO3 & 4514 & $\begin{array}{l}\text { Cytochrome c oxidase III } \\
\text { (COX3) }\end{array}$ & IV \\
\hline MT-ATP6 & 4508 & ATP synthase 6 & $\mathrm{~V}$ \\
\hline MT-ATP8 & 4509 & ATP synthase 8 & V \\
\hline
\end{tabular}

The remainder of the 37 genes in mitochondrial DNA encodes tRNAs and rRNAs.

(de Andrade et al. 2006). This is likely to explain perturbed GSIS in patients harbouring the mutations.

Previous studies have investigated whether common variations in mtDNA are associated with impaired insulin secretion and T2D. A variant at position 16189 has been shown to be associated with elevated fasting insulin concentrations (Poulton et al. 1998) and T2D in a population-based case-control study (Poulton et al. 2002). Other studies, however, have been unable to replicate this association (Chinnery et al. 2005, Mohlke et al. 2005, Das et al. 2007). Moreover, another study aimed to capture the entire common variation (except the hypervariable D-loop) in mtDNA and examine whether any of these variants are associated with T2D (Saxena et al. 2006). No significant associations between common mtDNA variants and T2D or related phenotypes, e.g., insulin secretion, were observed. In contrast, when polymorphisms in the coding region of mtDNA were genotyped in Asian casecontrol cohorts, carriers of a haplogroup N9a display a significantly reduced risk of T2D (Fuku et al. 2007). On balance, it seems that common variation in mtDNA is not a major pathogenetic factor of impaired $\beta$-cell function and increased risk of T2D.

\section{Transcriptional and translational control of mitochondrial function - TFB1/2M}

Transcription of mtDNA requires a specialized machinery, including factors necessary for promoter recognition, 
such as TFAM and TFB2M (Table 2). Mitochondrial transcription factor B1 (TFB1M) is alternatively known in protein databases as S-adenosylmethionine-6- $\mathrm{N}^{\prime}, \mathrm{N}^{\prime}$ adenosyl(rRNA)-dimethyltransferase. TFB1M was originally thought to serve as a transcription factor along with its paralog TFB2M; however, it is now established that it mainly functions as a dimethyl transferase. It dimethylates two highly conserved adjacent adenines in a stem-loop structure at the $3^{\prime}$ end of the $12 \mathrm{~S}$ rRNA (Metodiev et al. 2009). The covalent modification of $12 \mathrm{~S}$ rRNA is crucial for the stability of the small mitochondrial ribosomal subunit; mitochondrial translation is severely impaired in its absence.

We have identified a common variant (rs950994) in the human TFB1M gene (Koeck et al. 2011). It is associated with reduced insulin secretion, elevated postprandial glucose levels and future risk of T2D in females. Carriers of the risk allele exhibit decreased complex I activity and protein level in pancreatic islets (Koeck et al. 2011). Because islet TFB1M mRNA levels were lower in carriers of the risk allele and correlated with insulin secretion, we examined mice heterozygous for $T f b 1 m$ deficiency homozygous $\mathrm{Tfb} 1 \mathrm{~m}$ knockout mice are embryonically lethal (Metodiev et al. 2009). Heterozygous $\mathrm{Tfb} 1 \mathrm{~m}$ mice display lower expression of TFB1M in islets and impaired mitochondrial function; they release less insulin in response to glucose both in vivo and in vitro (Koeck et al. 2011). Moreover, silencing of TFB1M in clonal insulinsecreting cells impairs complexes of the mitochondrial OXPHOS system. Consequently, nutrient-stimulated ATP generation is reduced, leading to perturbed insulin secretion (Koeck et al. 2011).

Table 2 The mitochondrial transcriptional unit consists of the transcription factor $A$ and $B 2$, both of which are required for efficient transcription of the DNA.

\begin{tabular}{|c|c|c|c|}
\hline \multicolumn{4}{|c|}{ Mitochondrial transcriptional machinery } \\
\hline Gene name & Gene bank ID & Protein & Function \\
\hline TFAM & 7019 & $\begin{array}{l}\text { Transcription } \\
\text { factor A } \\
\text { mitochondrial }\end{array}$ & $\begin{array}{l}\text { Controls } \\
\text { mitochondrial } \\
\text { transcription }\end{array}$ \\
\hline TFB1M & 51106 & $\begin{array}{l}\text { Transcription } \\
\text { factor B1 } \\
\text { mitochondrial }\end{array}$ & $\begin{array}{l}\text { Stabilizes } \\
\text { mitochondrial } \\
12 S \text { rRNA }\end{array}$ \\
\hline TFB2M & 64216 & $\begin{array}{l}\text { Transcription } \\
\text { factor B2 } \\
\text { mitochondrial }\end{array}$ & $\begin{array}{l}\text { Controls } \\
\text { mitochondrial } \\
\text { transcription }\end{array}$ \\
\hline
\end{tabular}

TFB1M, on the other hand, is not a bona fide transcription factor. It functions as a methyl transferase, targeting two adjacent adenines in the 3 '-end of the mitochondrial $12 \mathrm{~S}$ ribosomal RNA. If this methylation is lost, ribosomes are destabilized and protein synthesis is abrogated.
These findings suggest that mitochondrial dysfunction is a causal pathogenetic process in the common form of human T2D. However, the underlying mechanisms and the precise role of TFB1M in pancreatic $\beta$-cells, however, remained unclear. To further understand the function of TFB1M and how it is associated with T2D, we created a mouse model with a $\beta$-cell-specific knockout of $\mathrm{Tfb} 1 \mathrm{~m}$ $\left(\beta-T f b 1 m^{-l-}\right)$, a mouse which gradually develops diabetes (Sharoyko et al. 2014). Prior to the onset of diabetes, $\beta$-Tfb1 $\mathrm{m}^{-/-}$mice exhibit retarded elimination of glucose owing to impaired insulin secretion. $\beta$ - $\mathrm{Tfb} 1 \mathrm{~m}^{-/-}$islets secrete less insulin in response to fuels, contain less insulin and secretory granules, as well as showing reduced $\beta$-cell mass (Sharoyko et al. 2014). Moreover, mitochondria in Tfb1m-deficient $\beta$-cells are more abundant, displaying a dysmorphic shape. We found that the levels of TFB1M and mitochondrial-encoded proteins, mitochondrial $12 \mathrm{~S}$ rRNA methylation, ATP production and oxygen consumption rate are all reduced in $\beta-T f b 1 m^{-/-}$islets. Furthermore, ROS levels in response to cellular stress are increased, whereas activation of defense mechanisms is attenuated. We also found signs of apoptosis and necrosis, as well as infiltration of macrophages and CD4+ cells in $\beta$-Tfb1m-l- islets. Our findings of cell death may also be relevant for human $\mathrm{T} 2 \mathrm{D}$, where $\beta$-cell loss and apoptosis in islets have been reported (Butler et al. 2003).

In summary, our findings demonstrated that $\mathrm{Tfb} 1 \mathrm{~m}$ deficiency in $\beta$-cells leads to mitochondrial dysfunction and subsequently diabetes owing to combined loss of $\beta$-cell function and mass. These observations reflect pathogenetic processes in human islets: using RNA sequencing, we found that the TFB1M risk variant exhibits a negative gene-dosage effect on islet TFB1M mRNA levels, as well as insulin secretion (Sharoyko et al. 2014). Thus, our studies highlight a pathogenetic and clinically relevant role of TFB1M in T2D.

Whilst the role of TFAM in pancreatic $\beta$-cells has been well characterised (Silva et al. 2000), it is only recently that we have elucidated the importance of TFB2M in mitochondrial and cellular function of pancreatic $\beta$-cells, using a mouse model of a $\beta$-cell specific homozygous and heterozygous knockout of $T f b 2 m$, as well as in rat clonal insulin-producing cells (Nicholas et al. 2017). A striking result of this study was how rapidly these perturbations evolve in $T f b 2 m$-deficient mice compared to those previously seen in mice with a $\beta$-cell-specific loss of either Tfam (Silva et al. 2000) or Tfb1m (Sharoyko et al. 2014). Loss of $T f b 2 m$ results in decreased expression of mitochondrial-encoded genes, as well as reduced mtDNA content. This leads to severe mitochondrial dysfunction, 
characterised by diminished hyperpolarisation of the inner mitochondrial membrane, impaired oxygen consumption and reduced ATP production. Importantly, we found that, in some instances, perturbation of $\beta$-cell metabolism leads to activation of compensatory mechanisms, limiting cellular dysfunction and damage. Ultimately, however, widespread mitochondrial dysfunction overwhelms cell-protective systems, such as mitochondrial unfolded protein response, leading to $\beta$-cell dysfunction as well as increased apoptosis and loss of $\beta$-cell mass. The rapid onset and dramatic consequences of TFB2M deficiency suggest an unforeseen critical role for this mitochondrial transcription factor (Nicholas et al. 2017).

Loss of $\mathrm{Tfb} 2 \mathrm{~m}$ in $\beta$-cells from 18-day-old $\beta$ - $\mathrm{Tfb} 2 \mathrm{~m}^{-/-}$ mice and in INS1 832/13 cells also activates both autophagy and mitophagy (Nicholas et al. 2017). An increased number of mitochondria targeted to LC3positive vesicles are observed, which implies either impaired autophagosome-lysosome fusion or increased autophagy flux through mitophagy. The lack of any major changes in expression of genes and proteins involved in mitophagy, however, supports the notion that mitophagic flux in $T f b 2 m$-deficient $\beta$-cells is impaired (Nicholas et al. 2017). Autophagy is also activated in response to ER stress. DDIT3, an ER stress marker, was increased in $\beta$-Tfb2m-l- islets and in TFB2Mdeficient clonal $\beta$-cells (Nicholas et al. 2017). DDIT3 also regulates the mitochondrial unfolded protein response, activated in response to mitochondrial stress upstream of the mitophagy pathway. Importantly, if cellular homeostasis is not kept by the autophagosomal machinery, cells could undergo cell death, either by activation of apoptosis or as a result of the inability to survive degradation of large amounts of cytoplasmic contents (De Duve \& Wattiaux 1966).

\section{Nuclear-encoded genes and control of mitochondrial function}

Mitochondria have arisen due to engulfment of an ancestral $\alpha$-proteobacterium by archaebacterium in an endosymbiotic event postulated to have occurred during early evolution (Lang et al. 1999). Thus, mtDNA is likely a remnant of primitive bacterial DNA. However, most of these genes have over time transmigrated into the nucleus and exert control over mitochondria as nuclear genes. Therefore, in addition to studies of the possible association of common variation in mtDNA and risk of T2D, it is warranted to establish whether polymorphisms in nuclear-encoded genes with control over mitochondria or directly involved in mitochondrial function are associated with $\mathrm{T} 2 \mathrm{D}$ and associated traits.

Impaired expression of the protein frataxin is responsible for the neurodegenerative disease Friedreich's ataxia. It is caused by an intronic GAA-triplet expansion. Frataxin is thought to play a role in the assembly of ironsulphur complexes (Puccio \& Koenig 2000), which are found in respiratory chain proteins, as well as in the TCA cycle enzymes, such as aconitase. These patients develop a fatal neurological disorder: one-third of patients also develop diabetes (Ristow et al. 2003, Ristow 2004, Cnop et al. 2013). Moreover, several studies have shown linkage of T2D with the FRDA locus (9q13) (Lindgren et al. 2002). $\beta$-cell-specific knockout mice for frataxin develop insulin-dependent diabetes with loss of $\beta$-cell mass, due to cellular growth arrest and increased apoptosis, which is paralleled by an increase of ROS in islets (Ristow et al. 2003). Friedreich's ataxia patients exhibit insulin resistance, which is not sufficiently compensated for by increased insulin secretion, evident from a reduced disposition index (Cnop et al. 2012). Moreover, silencing of frataxin in insulin-producing cells leads to impaired GSIS and increased rates of apoptosis (Cnop et al. 2012). Deficient ATP production in skeletal muscle has also been observed in Friedreich's ataxia patients (Lodi et al. 1999), which could contribute to impaired insulin sensitivity in the disease.

NDUFB6 encodes a protein, which is part of complex 1 of the respiratory chain; it is significantly downregulated in skeletal muscle from diabetic patients (Mootha et al. 2003). Carriers of A/A at rs540467 in NDUFB6 display a nominally increased risk of T2D in Scandinavian cohorts (Ling et al. 2007). Moreover, a polymorphism at rs629566 in the NDUFB6 promoter region creates a putative DNA methylation site; it is associated with an age-related decline in muscle NDUFB6 expression (Ling et al. 2007).

The gene encoding PGC- $1 \alpha$ is mapped to chromosomal region $4 \mathrm{p} 15.1$. This region has previously been linked to fasting serum insulin concentrations in Pima Indians (Pratley et al. 1998). Furthermore, variants, such as Gly482Ser, of PPARG1A are associated with T2D and with indices of $\beta$-cell function in some, but not all, studies (Ek et al. 2001, Lacquemant et al. 2002, Muller et al. 2003, Oberkofler et al. 2004, Vimaleswaran et al. 2005, Barroso et al. 2006, Sun et al. 2006). In isolated rodent islets and clonal $\beta$-cells, overexpression of PGC- $1 \alpha$ suppresses insulin secretion (Yoon et al. 2003). It has been shown that the PPARG1A Gly482Ser variant influences the expression of this gene in human pancreatic islets (Ling et al. 2008) and in human skeletal muscle 
(Ling et al. 2004). It was also demonstrated that expression of PPARG is reduced in islets from patients with T2D and that the expression level correlates with GSIS. Moreover, DNA methylation of the PPARG promoter is increased in T2D islets (Ling et al. 2008). At this point, the experimental in vitro work in some rodent models (Yoon et al. 2003), and observations on genetic and epigenetic regulation of PPARG1A in human pancreatic islets and its correlation with $\beta$-cell function are at odds. Clearly, more work in this important area needs to be performed.

Genetic variations in NRF1 are associated with T2D in a Korean case-control cohort (Cho et al. 2005). UCP-2 has been suggested to influence insulin secretion (Zhang et al. 2001, Joseph et al. 2002), and carriers of a UCP2 variant are at reduced risk of developing T2D (Bulotta et al. 2005). There is also a study suggesting that the mitochondrial leucyl tRNA synthase (LARS2) gene represents a T2D susceptibility gene (Maassen et al. 2005). Together, these studies highlight the important, but as of yet not completely resolved, role of genetic variation for mitochondrial function in the pathogenesis of T2D.

\section{Concluding remarks}

In this review, we have highlighted a number of factors and circumstances that underscore the pathogenetic role of mitochondrial perturbations in T2D (Fig. 3). Seemingly, metabolic disruption of $\beta$-cell function, which is a likely culprit in T2D, can be attributed to changes in mitochondrial enzymes and structural proteins as well as mitochondrial mass and morphology. These mitochondrial functions are likely subject to control by genetic and epigenetic mechanisms. The future will tell if these processes have a utility as therapeutic targets in T2D.

\section{Declaration of interest}

The authors declare that there is no conflict of interest that could be perceived as prejudicing the impartiality of this review.

\section{Funding}

The studies by the authors and which this review in part is based upon have been funded by the Swedish Research Council, The European Foundation for the Study of Diabetes, The Swedish Diabetes, Novo Nordisk, The Gyllenstiernska Krapperup and Albert Påhlsson Foundations, Diabetes Wellness, The Swedish Foundation for Strategic Research and the Medical Faculty in Lund, Sweden.

\section{Acknowledgements}

The authors thank all co-authors of their papers that have been reviewed here.

\section{References}

Abdul-Ghani MA, Tripathy D \& DeFronzo RA 2006 Contributions of beta-cell dysfunction and insulin resistance to the pathogenesis of impaired glucose tolerance and impaired fasting glucose. Diabetes Care 29 1130-1139. (https://doi.org/10.2337/dc05-2179)

Ahrén B 2000 Autonomic regulation of islet hormone secretionimplications for health and disease. Diabetologia 43 393-410. (https:// doi.org/10.1007/s001250051322)

Ahrén B 2005 Type 2 diabetes, insulin secretion and beta-cell mass. Current Molecular Medicine 5 275-286.

Ahrén B, Simonsson E, Scheurink AJ, Mulder H, Myrsén U \& Sundler F 1997 Dissociated insulinotropic sensitivity to glucose and carbachol in high-fat diet-induced insulin resistance in C57BL/6J mice. Metabolism: Clinical and Experimental 46 97-106.

Anello M, Lupi R, Spampinato D, Piro S, Masini M, Boggi U, Del Prato S, Rabuazzo AM, Purrello F \& Marchetti P 2005 Functional and morphological alterations of mitochondria in pancreatic beta cells from type 2 diabetic patients. Diabetologia 48 282-289. (https://doi. org/10.1007/s00125-004-1627-9)

Ashcroft FM \& Rorsman P 2012 Diabetes mellitus and the beta cell: the last ten years. Cell 148 1160-1171. (https://doi.org/10.1016/j. cell.2012.02.010)

Bagdade JD, Bierman EL \& Porte D Jr 1967 The significance of basal insulin levels in the evaluation of the insulin response to glucose in diabetic and nondiabetic subjects. Journal of Clinical Investigation $\mathbf{4 6}$ 1549-1557. (https://doi.org/10.1172/JCI105646)

Barroso I, Luan J, Sandhu MS, Franks PW, Crowley V, Schafer AJ, O'Rahilly S \& Wareham NJ 2006 Meta-analysis of the Gly482Ser variant in PPARGC1A in type 2 diabetes and related phenotypes. Diabetologia 49 501-505. (https://doi.org/10.1007/s00125-0050130-2)

Bertrand G, Ishiyama N, Nenquin M, Ravier MA \& Henquin JC 2002 The elevation of glutamate content and the amplification of insulin secretion in glucose-stimulated pancreatic islets are not causally related. Journal of Biological Chemistry 277 32883-32891. (https://doi. org/10.1074/jbc.M205326200)

Bulotta A, Ludovico O, Coco A, Di Paola R, Quattrone A, Carella M, Pellegrini F, Prudente S \& Trischitta V 2005 The common-866G/A polymorphism in the promoter region of the UCP-2 gene is associated with reduced risk of type 2 diabetes in Caucasians from Italy. Journal of Clinical Endocrinology and Metabolism 90 1176-1180. (https://doi. org/10.1210/jc.2004-1072)

Butler AE, Janson J, Bonner-Weir S, Ritzel R, Rizza RA \& Butler PC 2003 Beta-cell deficit and increased beta-cell apoptosis in humans with type 2 diabetes. Diabetes 52 102-110. (https://doi.org/10.2337/ diabetes.52.1.102)

Chan CB, MacDonald PE, Saleh MC, Johns DC, Marban E \& Wheeler MB 1999 Overexpression of uncoupling protein 2 inhibits glucosestimulated insulin secretion from rat islets. Diabetes 48 1482-1486. (https://doi.org/10.2337/diabetes.48.7.1482)

Chinnery PF, Elliott HR, Patel S, Lambert C, Keers SM, Durham SE, McCarthy MI, Hitman GA, Hattersley AT \& Walker M 2005 Role of the mitochondrial DNA 16184-16193 poly-C tract in type 2 diabetes. Lancet 366 1650-1651. (https://doi.org/10.1016/S01406736(05)67492-2)

Cho YM, Shin HD, Park BL, Kim JH, Park KS, Kim SY \& Lee HK 2005 Association between polymorphisms in the nuclear respiratory factor 1 gene and type 2 diabetes mellitus in the Korean population. http://joe.endocrinology-journals.org

https://doi.org/10.1530/JOE-17-0367 (c) 2018 Society for Endocrinology Published by Bioscientifica Ltd. 
Diabetologia 48 2033-2038. (https://doi.org/10.1007/s00125-0051855-7)

Cipolat S, Martins de Brito O, Dal Zilio B \& Scorrano L 2004 OPA1 requires mitofusin 1 to promote mitochondrial fusion. PNAS 101 15927-15932. (https://doi.org/10.1073/pnas.0407043101)

Cnop M, Igoillo-Esteve M, Rai M, Begu A, Serroukh Y, Depondt C, Musuaya AE, Marhfour I, Ladriere L, Lopez XM, et al. 2012 Central role and mechanisms of beta-cell dysfunction and death in Friedreich ataxia-associated diabetes. Annals of Neurology 72 971-982. (https:// doi.org/10.1002/ana.23698)

Cnop M, Mulder H \& Igoillo-Esteve M 2013 Diabetes in Friedreich ataxia. Journal of Neurochemistry 126 94-102. (https://doi.org/10.1111/ jnc.12216)

Das S, Bennett AJ, Sovio U, Ruokonen A, Martikainen H, Pouta A, Hartikainen AL, Franks S, Elliott P, Poulton J, et al. 2007 Detailed analysis of variation at and around mitochondrial position 16189 in a large Finnish cohort reveals no significant associations with early growth or metabolic phenotypes at age 31 years. Journal of Clinical Endocrinology and Metabolism 92 3219-3223. (https://doi.org/10.1210/ jc.2007-0702)

de Andrade PBM, Rubi B, Frigerio F, van den Ouweland JMW, Maassen JA \& Maechler P 2006 Diabetes-associated mitochondrial DNA mutation A3243G impairs cellular metabolic pathways necessary for beta cell function. Diabetologia 49 1816-1826. (https://doi.org/10.1007/ s00125-006-0301-9)

De Duve C \& Wattiaux R 1966 Functions of lysosomes. Annual Review of Physiology 28 435. (https://doi.org/10.1146/annurev. ph.28.030166.002251)

Del Guerra S, Lupi R, Marselli L, Masini M, Bugliani M, Sbrana S, Torri S, Pollera M, Boggi U, Mosca F, et al. 2005 Functional and molecular defects of pancreatic islets in human type 2 diabetes. Diabetes $\mathbf{5 4}$ 727-735. (https://doi.org/10.2337/diabetes.54.3.727)

Deng S, Vatamaniuk M, Huang X, Doliba N, Lian MM, Frank A, Velidedeoglu E, Desai NM, Koeberlein B, Wolf B, et al. 2004 Structural and functional abnormalities in the islets isolated from type 2 diabetic subjects. Diabetes 53 624-632. (https://doi.org/10.2337/ diabetes.53.3.624)

Detmer SA \& Chan DC 2007 Functions and dysfunctions of mitochondrial dynamics. Nature Reviews Molecular Cell Biology $\mathbf{8}$ 870-879. (https://doi.org/10.1038/nrm2275)

Ek J, Andersen G, Urhammer SA, Gaede PH, Drivsholm T, BorchJohnsen K, Hansen T \& Pedersen O 2001 Mutation analysis of peroxisome proliferator-activated receptor-gamma coactivator-1 (PGC-1) and relationships of identified amino acid polymorphisms to Type II diabetes mellitus. Diabetologia 44 2220-2226. (https://doi. org/10.1007/s001250100032)

Ekstrand MI, Falkenberg M, Rantanen A, Park CB, Gaspari M, Hultenby K, Rustin P, Gustafsson CM \& Larsson NG 2004 Mitochondrial transcription factor A regulates mtDNA copy number in mammals. Human Molecular Genetics 13 935-944. (https://doi.org/10.1093/hmg/ ddh109)

Eto K, Tsubamoto Y, Terauchi Y, Sugiyama T, Kishimoto T, Takahashi N, Yamauchi N, Kubota N, Murayama S, Aizawa T, et al. 1999 Role of NADH shuttle system in glucose-induced activation of mitochondrial metabolism and insulin secretion. Science 283 981-985. (https://doi. org/10.1126/science.283.5404.981)

Fajans SS, Bell GI \& Polonsky KS 2001 Molecular mechanisms and clinical pathophysiology of maturity-onset diabetes of the young. New England Journal of Medicine 345 971-980. (https://doi.org/10.1056/ NEJMra002168)

Fernandez-Alvarez J, Conget I, Rasschaert J, Sener A, Gomis R \& Malaisse WJ 1994 Enzymatic, metabolic and secretory patterns in human islets of type-2 (non-insulin-dependent) diabetic-patients. Diabetologia 37 177-181. (https://doi.org/10.1007/s001250050090)

Fex M, Dekker Nitert M, Wierup N, Ling C, Sundler F \& Mulder H $2007 a$ Enhanced mitochondrial metabolism may account for the adaptation to insulin resistance in islets from high fat diet-fed C57BL/6J mice. Diabetologia 50 74-83. (https://doi.org/10.1007/ s00125-006-0464-4)

Fex M, Wierup N, Nitert MD, Ristow M \& Mulder H 2007b Rat insulin promoter 2-Cre recombinase mice bred onto a pure C57BL/6J background exhibit unaltered glucose tolerance. Journal of Endocrinology 194 551-555. (https://doi.org/10.1677/JOE-07-0161)

Frezza C, Cipolat S, Martins de Brito O, Micaroni M, Beznoussenko GV, Rudka T, Bartoli D, Polishuck RS, Danial NN, De Strooper B, et al. 2006 OPA1 controls apoptotic cristae remodeling independently from mitochondrial fusion. Cell 126 177-189. (https://doi.org/10.1016/j. cell.2006.06.025)

Fuchsberger C, Flannick J, Teslovich TM, Mahajan A, Agarwala V, Gaulton KJ, Ma C, Fontanillas P, Moutsianas L, McCarthy DJ, et al. 2016 The genetic architecture of type 2 diabetes. Nature 536 41-47. (https://doi.org/10.1038/nature18642)

Fuku N, Park KS, Yamada Y, Nishigaki Y, Cho YM, Matsuo H, Segawa T, Watanabe S, Kato K, Yokoi K, et al. 2007 Mitochondrial haplogroup N9a confers resistance against type 2 diabetes in Asians. American Journal of Human Genetics 80 407-415. (https://doi. org/10.1086/512202)

Gaulton KJ, Ferreira T, Lee Y, Raimondo A, Magi R, Reschen ME, Mahajan A, Locke A, William Rayner N, Robertson N, et al. 2015 Genetic fine mapping and genomic annotation defines causal mechanisms at type 2 diabetes susceptibility loci. Nature Genetics $\mathbf{4 7}$ 1415-1425. (https://doi.org/10.1038/ng.3437)

Gerencser AA, Mulder H \& Nicholls DG 2015 Calcium modulation of exocytosis-linked plasma membrane potential oscillations in INS-1 832/13 cells. Biochemical Journal 471 111-122. (https://doi org/10.1042/BJ20150616)

Glaser B, Kesavan P, Heyman M, Davis E, Cuesta A, Buchs A, Stanley CA, Thornton PS, Permutt MA, Matschinsky FM, et al. 1998 Familial hyperinsulinism caused by an activating glucokinase mutation. New England Journal of Medicine 338 226-230. (https://doi.org/10.1056/ NEJM199801223380404)

Goehring I, Gerencser AA, Schmidt S, Brand MD, Mulder H \& Nicholls DG 2012 Plasma membrane potential oscillations in insulin secreting Ins-1 832/13 cells do not require glycolysis and are not initiated by fluctuations in mitochondrial bioenergetics. Journal of Biological Chemistry 287 15706-15717. (https://doi.org/10.1074/jbc. M111.314567)

Goehring I, Sharoyko VV, Malmgren S, Andersson LE, Spegel P, Nicholls DG \& Mulder H 2014 Chronic high glucose and pyruvate levels differentially affect mitochondrial bioenergetics and fuelstimulated insulin secretion from clonal INS-1 832/13 cells. Journal of Biological Chemistry 289 3786-3798. (https://doi.org/10.1074/jbc. M113.507335)

Gooding JR, Jensen MV, Dai X, Wenner BR, Lu D, Arumugam R, Ferdaoussi M, MacDonald PE \& Newgard CB 2015 Adenylosuccinate is an insulin secretagogue derived from glucose-induced purine metabolism. Cell Reports 13 157-167. (https://doi.org/10.1016/j. celrep.2015.08.072)

Handschin C \& Spiegelman BM 2006 Peroxisome proliferator-activated receptor gamma coactivator 1 coactivators, energy homeostasis, and metabolism. Endocrine Reviews 27 728-735. (https://doi.org/10.1210/ er.2006-0037)

Henquin JC 2000 Triggering and amplifying pathways of regulation of insulin secretion by glucose. Diabetes 49 1751-1760. (https://doi. org/10.2337/diabetes.49.11.1751)

Ivarsson R, Quintens R, Dejonghe S, Tsukamoto K, in 't Veld P, Renström E \& Schuit FC 2005 Redox control of exocytosis: regulatory role of NADPH, thioredoxin, and glutaredoxin. Diabetes $\mathbf{5 4}$ 2132-2142. (https://doi.org/10.2337/diabetes.54.7.2132)

Jin SM \& Youle RJ 2012 PINK1-and Parkin-mediated mitophagy at a glance. Journal of Cell Science 125 795-799. (https://doi.org/10.1242/ jcs.093849) http://joe.endocrinology-journals.org https://doi.org/10.1530/JOE-17-0367
(C) 2018 Society for Endocrinology Published by Bioscientifica Ltd. Printed in Great Britain 
Jonas JC, Li GD, Palmer M, Weller U \& Wollheim CB 1994 Dynamics of $\mathrm{Ca}^{2+}$ and guanosine 5'-triphosphate action on insulin-secretion from alpha-toxin-permeabilized hit-T15 cells. Biochemical Journal 301 523-529. (https://doi.org/10.1042/bj3010523)

Jonas JC, Bensellam M, Duprez J, Elouil H, Guiot Y \& Pascal SM 2009 Glucose regulation of islet stress responses and beta-cell failure in type 2 diabetes. Diabetes, Obesity and Metabolism 11 (Supplement 4) 65-81. (https://doi.org/10.1111/j.1463-1326.2009.01112.x)

Joseph JW, Koshkin V, Zhang CY, Wang J, Lowell BB, Chan CB \& Wheeler MB 2002 Uncoupling protein 2 knockout mice have enhanced insulin secretory capacity after a high-fat diet. Diabetes $\mathbf{5 1}$ 3211-3219. (https://doi.org/10.2337/diabetes.51.11.3211)

Jung SR, Kuok IT, Couron D, Rizzo N, Margineantu DH, Hockenbery DM, Kim F \& Sweet IR 2011 Reduced cytochrome C is an essential regulator of sustained insulin secretion by pancreatic islets. Journal of Biological Chemistry 286 17422-17434. (https://doi.org/10.1074/jbc. M110.202820)

Kasuga M 2006 Insulin resistance and pancreatic beta cell failure. Journal of Clinical Investigation 116 1756-1760. (https://doi.org/10.1172/JCI29189)

Kennedy ED, Rizzuto R, Theler JM, Pralong WF, Bastianutto C, Pozzan T \& Wollheim CB 1996 Glucose-stimulated insulin secretion correlates with changes in mitochondrial and cytosolic $\mathrm{Ca} 2+$ in aequorinexpressing INS-1 cells. Journal of Clinical Investigation 98 2524-2538. (https://doi.org/10.1172/JCI119071)

Kim I, Rodriguez-Enriquez S \& Lemasters JJ 2007 Selective degradation of mitochondria by mitophagy. Archives of Biochemistry and Biophysics 462 245-253. (https://doi.org/10.1016/j.abb.2007.03.034)

Koeck T, Olsson AH, Nitert MD, Sharoyko VV, Ladenvall C, Kotova O, Reiling E, Rönn T, Parikh H, Taneera J, et al. 2011 A common variant in TFB1M is associated with reduced insulin secretion and increased future risk of type 2 diabetes. Cell Metabolism 13 80-91. (https://doi. org/10.1016/j.cmet.2010.12.007)

Lacquemant C, Chikri M, Boutin P, Samson C \& Froguel P 2002 No association between the $\mathrm{G} 482 \mathrm{~S}$ polymorphism of the proliferatoractivated receptor-gamma coactivator-1 (PGC-1) gene and Type II diabetes in French Caucasias. Diabetologia 45 602-603. (https://doi. org/10.1007/s00125-002-0783-z)

Lang BF, Gray MW \& Burger G 1999 Mitochondrial genome evolution and the origin of eukaryotes. Annual Review of Genetics 33 351-397. (https://doi.org/10.1146/annurev.genet.33.1.351)

Lee YJ, Jeong SY, Karbowski M, Smith CL \& Youle RJ 2004 Roles of the mammalian mitochondrial fission and fusion mediators Fis1, Drp1, and Opa1 in apoptosis. Molecular Biology of the Cell 15 5001-5011. (https://doi.org/10.1091/mbc.E04-04-0294)

Lee S, Jeong SY, Lim WC, Kim S, Park YY, Sun X, Youle RJ \& Cho H 2007 Mitochondrial fission and fusion mediators, hFis1 and OPA1, modulate cellular senescence. Journal of Biological Chemistry 282 22977-22983. (https://doi.org/10.1074/jbc.M700679200)

Liesa M \& Shirihai OS 2013 Mitochondrial dynamics in the regulation of nutrient utilization and energy expenditure. Cell Metabolism 17 491-506. (https://doi.org/10.1016/j.cmet.2013.03.002)

Lindgren CM, Mahtani MM, Widen E, McCarthy MI, Daly MJ, Kirby A, Reeve MP, Kruglyak L, Parker A, Meyer J, et al. 2002 Genomewide search for type 2 diabetes mellitus susceptibility loci in Finnish families: the Botnia study. American Journal of Human Genetics 70 509-516. (https://doi.org/10.1086/338629)

Ling C, Poulsen P, Carlsson E, Ridderstrale M, Almgren P, Wojtaszewski J, Beck-Nielsen H, Groop L \& Vaag A 2004 Multiple environmental and genetic factors influence skeletal muscle PGC-1alpha and PGC1beta gene expression in twins. Journal of Clinical Investigation 114 1518-1526. (https://doi.org/10.1172/JCI21889)

Ling C, Poulsen P, Simonsson S, Rönn T, Holmkvist J, Almgren P, Hagert P, Nilsson E, Mabey AG, Nilsson P, et al. 2007 Genetic and epigenetic factors are associated with expression of respiratory chain component NDUFB6 in human skeletal muscle. Journal of Clinical Investigation 117 3427-3435. (https://doi.org/10.1172/JCI30938)
Ling C, Del Guerra S, Lupi R, Rönn T, Granhall C, Luthman H, Masiello P, Marchetti P, Groop L \& Del Prato S 2008 Epigenetic regulation of PPARGC1A in human type 2 diabetic islets and effect on insulin secretion. Diabetologia 51 615-622. (https://doi.org/10.1007/s00125007-0916-5)

Liu L, Feng D, Chen G, Chen M, Zheng QX, Song PP, Ma Q, Zhu CZ, Wang R, Qi WJ, et al. 2012 Mitochondrial outer-membrane protein FUNDC1 mediates hypoxia-induced mitophagy in mammalian cells. Nature Cell Biology 14 177-185. (https://doi.org/10.1038/ncb2422)

Lodi R, Cooper JM, Bradley JL, Manners D, Styles P, Taylor DJ \& Schapira AH 1999 Deficit of in vivo mitochondrial ATP production in patients with Friedreich ataxia. PNAS 96 11492-11495. (https://doi. org/10.1073/pnas.96.20.11492)

Lupi R, Marselli L, Dionisi S, Del Guerra S, Boggi U, Del Chiaro M, Lencioni C, Bugliani M, Mosca F, Di Mario U, et al. 2004 Improved insulin secretory function and reduced chemotactic properties after tissue culture of islets from type 1 diabetic patients. Diabetes/ Metabolism Research 20 246-251. (https://doi.org/10.1002/dmrr.460)

Maassen JA, Jansen JJ, Kadowaki T, van den Ouweland JM, t Hart LM \& Lemkes HH 1996 The molecular basis and clinical characteristics of Maternally Inherited Diabetes and Deafness (MIDD), a recently recognized diabetic subtype. Experimental and Clinical Endocrinology and Diabetes 104 205-211. (https://doi.org/10.1055/s-0029-1211444)

Maassen JA, Janssen GM \& t Hart LM 2005 Molecular mechanisms of mitochondrial diabetes (MIDD). Annals of Medicine 37 213-221. (https://doi.org/10.1080/07853890510007188)

MacDonald MJ, Longacre MJ, Langberg EC, Tibell A, Kendrick MA, Fukao T \& Ostenson CG 2009 Decreased levels of metabolic enzymes in pancreatic islets of patients with type 2 diabetes. Diabetologia $\mathbf{5 2}$ 1087-1091. (https://doi.org/10.1007/s00125-009-1319-6)

Maechler P \& Wollheim CB 1999 Mitochondrial glutamate acts as a messenger in glucose-induced insulin exocytosis (see comments). Nature 402 685-689. (https://doi.org/10.1038/45280)

Maechler P, Carobbio S \& Rubi B 2006 In beta-cells, mitochondria integrate and generate metabolic signals controlling insulin secretion. International Journal of Biochemistry and Cell Biology 38 696-709. (https://doi.org/10.1016/j.biocel.2005.12.006)

Malmgren S, Nicholls DG, Taneera J, Bacos K, Koeck T, Tamaddon A, Wibom R, Groop L, Ling C, Mulder H, et al. 2009 Tight coupling between glucose and mitochondrial metabolism in clonal betacells is required for robust insulin secretion. Journal of Biological Chemistry 284 32395-32404. (https://doi.org/10.1074/jbc. M109.026708)

Mannella CA 2006 Structure and dynamics of the mitochondrial inner membrane cristae. Biochimica et Biophysica Acta 1763 542-548. (https://doi.org/10.1016/j.bbamcr.2006.04.006)

Meier JJ, Breuer TGK, Bonadonna RC, Tannapfel A, Uhl W, Schmidt WE, Schrader H \& Menge BA 2012 Pancreatic diabetes manifests when beta cell area declines by approximately $65 \%$ in humans. Diabetologia 55 1346-1354. (https://doi.org/10.1007/ s00125-012-2466-8)

Metodiev M, Lesko N, Park CB, Cámara Y, Shi Y, Wibom R, Hultenby K, Gustafsson CM \& Larsson NG 2009 Methylation of 12S rRNA is necessary for in vivo stability of the small subunit of the mammalian mitochondrial ribosome. Cell Metabolism 9 1-12. (https://doi. org/10.1016/j.cmet.2008.12.011)

Mohlke KL, Jackson AU, Scott LJ, Peck EC, Suh YD, Chines PS, Watanabe RM, Buchanan TA, Conneely KN, Erdos MR, et al. 2005 Mitochondrial polymorphisms and susceptibility to type 2 diabetesrelated traits in Finns. Human Genetics 118 245-254. (https://doi. org/10.1007/s00439-005-0046-4)

Mootha VK, Lindgren CM, Eriksson KF, Subramanian A, Sihag S, Lehar J, Puigserver P, Carlsson E, Ridderstrale M, Laurila E, et al. 2003 PGC1alpha-responsive genes involved in oxidative phosphorylation are coordinately downregulated in human diabetes. Nature Genetics $\mathbf{3 4}$ 267-273. (https://doi.org/10.1038/ng1180) 
Mulder H 2017 Transcribing beta-cell mitochondria in health and disease. Molecular Metabolism 6 1040-1051. (https://doi.org/10.1016/j. molmet.2017.05.014)

Mulder H \& Ling C 2009 Mitochondrial dysfunction in pancreatic beta-cells in type 2 diabetes. Molecular and Cellular Endocrinology 297 34-40. (https://doi.org/10.1016/j.mce.2008.05.015)

Muller YL, Bogardus C, Pedersen O \& Baier L 2003 A Gly482Ser missense mutation in the peroxisonte proliferator-activated receptor gamma coactivator- 1 is associated with altered lipid oxidation and early insulin secretion in Pima Indians. Diabetes 52 895-898. (https://doi. org/10.2337/diabetes.52.3.895)

Muoio DM \& Newgard CB 2008 Mechanisms of disease: molecular and metabolic mechanisms of insulin resistance and beta-cell failure in type 2 diabetes. Nature Reviews Molecular Cell Biology 9 193-205. (https://doi.org/10.1038/nrm2327)

Ng HJ \& Gloyn AL 2013 Bridging the gap between genetic associations and molecular mechanisms for type 2 diabetes. Current Diabetes Reports 13 778-785. (https://doi.org/10.1007/s11892-013-0429-1)

Nicholas LM, Valtat B, Medina-Benavente A, Andersson LE, Abels M, Mollet IG, Jain D, Eliasson L, Wierup N, Fex M, et al. 2017 Mitochondrial transcription factor B2 is essential for mitochondrial and cellular function in pancreatic $\beta$-cells. Molecular Metabolism 6 651-663. (https://doi.org/10.1016/j.molmet.2017.05.005)

Nicholls DG 2006 The physiological regulation of uncoupling proteins. Biochimica et Biophysica Acta 1757 459-466. (https://doi. org/10.1016/j.bbabio.2006.02.005)

Nicholls DG 2016 The pancreatic beta-cell: a bioenergetic perspective. Physiological Reviews 96 1385-1447. (https://doi.org/10.1152/ physrev.00009.2016)

Oberkofler H, Linnemayr V, Weitgasser R, Klein K, Xie MQ, Iglseder B, Krempler F, Paulweber B \& Patsch W 2004 Complex haplotypes of the PGC-1 alpha gene are associated with carbohydrate metabolism and type 2 diabetes. Diabetes 53 1385-1393. (https://doi.org/10.2337/ diabetes.53.5.1385)

Otonkoski T, Jiao H, Kaminen-Ahola N, Tapia-Paez I, Ullah MS, Parton LE, Schuit F, Quintens R, Sipila I, Mayatepek E, et al. 2007 Physical exercise-induced hypoglycemia caused by failed silencing of monocarboxylate transporter 1 in pancreatic beta cells. American Journal of Human Genetics 81 467-474. (https://doi. org/10.1086/520960)

Pi JB, Bai YS, Daniel KW, Liu DX, Lyght O, Edelstein D, Brownlee M, Corkey BE \& Collins S 2009 Persistent oxidative stress due to absence of uncoupling protein 2 associated with impaired pancreatic beta-cell function. Endocrinology 150 3040-3048. (https://doi.org/10.1210/ en.2008-1642)

Poitout V, Amyot J, Semache M, Zarrouki B, Hagman D \& Fontes G 2010 Glucolipotoxicity of the pancreatic beta cell. Biochimica et Biophysica Acta: Molecular and Cell Biology of Lipids 1801 289-298. (https://doi. org/10.1016/j.bbalip.2009.08.006)

Poulton J, Brown MS, Cooper A, Marchington DR \& Phillips DIW 1998 A common mitochondrial DNA variant is associated with insulin resistance in adult life. Diabetologia 41 54-58. (https://doi. org/10.1007/s001250050866)

Poulton J, Bednarz AL, Scott-Brown M, Thompson C, Macaulay VA \& Simmons D 2002 The presence of a common mitochondrial DNA variant is associated with fasting insulin levels in Europeans in Auckland. Diabetic Medicine 19 969-971. (https://doi.org/10.1046/ j.0742-3071.2002.00836.x)

Prasad RB \& Groop L 2015 Genetics of type 2 diabetes-pitfalls and possibilities. Genes 6 87-123. (https://doi.org/10.3390/ genes6010087)

Pratley RE, Thompson DB, Prochazka M, Baier L, Mott D, Ravussin E, Sakul H, Ehm MG, Burns DK, Foroud T, et al. 1998 An autosomal genomic scan for loci linked to prediabetic phenotypes in Pima Indians. Journal of Clinical Investigation 101 1757-1764. (https://doi. org/10.1172/JCI1850)
Prentki M \& Corkey BE 1996 Are the beta-cell signaling molecules malonyl-CoA and cystolic long-chain acyl-CoA implicated in multiple tissue defects of obesity and NIDDM? Diabetes 45 273-283. (https:// doi.org/10.2337/diab.45.3.273)

Puccio H \& Koenig M 2000 Recent advances in the molecular pathogenesis of Friedreich ataxia. Human Molecular Genetics 9 887-892. (https://doi.org/10.1093/hmg/9.6.887)

Pullen TJ, Khan AM, Barton G, Butcher SA, Sun G \& Rutter GA 2010 Identification of genes selectively disallowed in the pancreatic islet. Islets 2 89-95. (https://doi.org/10.4161/isl.2.2.11025)

Reimer MK \& Ahrén B 2002 Altered beta-cell distribution of pdx-1 and GLUT-2 after a short-term challenge with a high-fat diet in C57BL/6J mice. Diabetes 51 (Supplement 1) S138-S143. (https://doi. org/10.2337/diabetes.51.2007.S138)

Ristow M 2004 Neurodegenerative disorders associated with diabetes mellitus. Journal of Molecular Medicine 82 510-529.

Ristow M, Mulder H, Pomplun D, Schulz TJ, Muller-Schmehl K, Krause A, Fex M, Puccio H, Muller J, Isken F, et al. 2003 Frataxin deficiency in pancreatic islets causes diabetes due to loss of beta cell mass. Journal of Clinical Investigation 112 527-534. (https://doi.org/10.1172/JCI18107)

Santos LRB, Muller C, de Souza AH, Takahashi HK, Spegel P, Sweet IR, Chae H, Mulder H \& Jonas JC 2017 NNT reverse mode of operation mediates glucose control of mitochondrial NADPH and glutathione redox state in mouse pancreatic $\beta$-cells. Molecular Metabolism 6 535-547. (https://doi.org/10.1016/j.molmet.2017.04.00)

Saxena R, de Bakker PIW, Singer K, Mootha V, Burtt N, Hirschhorn JN, Gaudet D, Isomaa B, Daly MJ, Groop L, et al. 2006 Comprehensive association testing of common mitochondrial DNA variation in metabolic disease. American Journal of Human Genetics 79 54-61. (https://doi.org/10.1086/504926)

Saxena R, Voight BF, Lyssenko V, Burtt NP, de Bakker PI, Chen H, Roix JJ, Kathiresan S, Hirschhorn JN, Daly MJ, et al. 2007 Genomewide association analysis identifies loci for type 2 diabetes and triglyceride levels. Science 316 1331-1336. (https://doi.org/10.1126/ science.1142358)

Scarpulla RC 2008 Transcriptional paradigms in mammalian mitochondrial biogenesis and function. Physiological Reviews $\mathbf{8 8}$ 611-638. (https://doi.org/10.1152/physrev.00025.2007)

Schuit F, De Vos A, Farfari S, Moens K, Pipeleers D, Brun T \& Prentki M 1997 Metabolic fate of glucose in purified islet cells. Glucose-regulated anaplerosis in beta cells. Journal of Biological Chemistry $\mathbf{2 7 2}$ 18572-18579. (https://doi.org/10.1074/jbc.272.30.18572)

Schultz J, Waterstradt R, Kantowski T, Rickmann A, Reinhardt F, Sharoyko V, Mulder H, Tiedge M \& Baltrusch S 2016 Precise expression of Fis1 is important for glucose responsiveness of beta cells. Journal of Endocrinology 230 81-91. (https://doi.org/10.1530/ JOE-16-0111)

Scott LJ, Mohlke KL, Bonnycastle LL, Willer CJ, Li Y, Duren WL, Erdos MR, Stringham HM, Chines PS, Jackson AU, et al. 2007 A genome-wide association study of type 2 diabetes in Finns detects multiple susceptibility variants. Science 316 1341-1345. (https://doi. org/10.1126/science.1142382)

Sharoyko VV, Abels M, Sun J, Nicholas LM, Mollet IG, Stamenkovic JA, Göhring I, Malmgren S, Storm P, Fadista J, et al. 2014 Loss of TFB1M results in mitochondrial dysfunction that leads to impaired insulin secretion and diabetes. Human Molecular Genetics 23 5733-5749. (https://doi.org/10.1093/hmg/ddu288)

Silva JP, Kohler M, Graff C, Oldfors A, Magnuson MA, Berggren PO \& Larsson NG 2000 Impaired insulin secretion and beta-cell loss in tissue-specific knockout mice with mitochondrial diabetes. Nature Genetics 26 336-340. (https://doi.org/10.1038/81649)

Simpson RG, Benedetti A, Grodsky GM, Karam JH \& Forsham PH 1968 Early phase of insulin release. Diabetes 17 684-692. (https://doi. org/10.2337/diab.17.11.684)

Sladek R, Rocheleau G, Rung J, Dina C, Shen L, Serre D, Boutin P, Vincent D, Belisle A, Hadjadj S, et al. 2007 A genome-wide association 
study identifies novel risk loci for type 2 diabetes. Nature $\mathbf{4 4 5}$ 881-885. (https://doi.org/10.1038/nature05616)

Soleimanpour SA, Ferrari AM, Raum JC, Groff DN, Yang JX, Kaufman BA \& Stoffers DA 2015 Diabetes susceptibility genes Pdx1 and Clec16a function in a pathway regulating mitophagy in beta-cells. Diabetes $\mathbf{6 4}$ 3475-3484. (https://doi.org/10.2337/db15-0376)

Spégel P, Sharoyko VV, Goehring I, Danielsson AP, Malmgren S, Nagorny CL, Andersson LE, Koeck T, Sharp GW, Straub SG, et al. 2013 Time-resolved metabolomics analysis of beta-cells implicates the pentose phosphate pathway in the control of insulin release. Biochemical Journal 450 595-605. (https://doi.org/10.1042/ BJ20121349)

Spégel P, Andersson LA, StormP,Sharoyko VV, Göhring I, Rosengren A \& Mulder H 2015 Unique and shared metabolic regulation in clonal $\beta$-cells and primary islets derived from rat revealed by metabolomics analysis. American Journal of Physiology 156 1995-2005. (https://doi. org/10.1210/en.2014-1391)

Stanley CA, Lieu YK, Hsu BY, Burlina AB, Greenberg CR, Hopwood NJ, Perlman K, Rich BH, Zammarchi E \& Poncz M 1998 Hyperinsulinism and hyperammonemia in infants with regulatory mutations of the glutamate dehydrogenase gene. New England Journal of Medicine 338 1352-1357. (https://doi.org/10.1056/NEJM199805073381904)

Sun L, Yang Z, Jin F, Zhu XQ, Qu YC, Shi XH \& Wang L 2006 The Gly482Ser variant of the PPARGC1 gene is associated with Type 2 diabetes mellitus in northern Chinese, especially men. Diabetic Medicine 23 1085-1092. (https://doi.org/10.1111/j.14645491.2006.01949.x)

Supale S, Li N, Brun T \& Maechler P 2012 Mitochondrial dysfunction in pancreatic beta cells. Trends in Endocrinology and Metabolism 23 477-487. (https://doi.org/10.1016/j.tem.2012.06.002)

Supale S, Thorel F, Merkwirth C, Gjinovci A, Herrera PL, Scorrano L, Meda P, Langer T \& Maechler P 2013 Loss of prohibitin induces mitochondrial damages altering beta-cell function and survival and is responsible for gradual diabetes development. Diabetes 62 3488-3499. (https://doi.org/10.2337/db13-0152)

Thorrez L, Laudadio I, Van Deun K, Quintens R, Hendrickx N, Granvik M, Lemaire K, Schraenen A, Van Lommel L, Lehnert S, et al. 2011 Tissuespecific disallowance of housekeeping genes: the other face of cell differentiation. Genome Research 21 95-105. (https://doi.org/10.1101/ gr.109173.110)

Toye AA, Lippiat JD, Proks P, Shimomura K, Bentley L, Hugill A, Mijat V, Goldsworthy M, Moir L, Haynes A, et al. 2005 A genetic and physiological study of impaired glucose homeostasis control in C57BL/6J mice. Diabetologia 48 675-686. (https://doi.org/10.1007/ s00125-005-1680-z)

Trifunovic A \& Larsson NG 2008 Mitochondrial dysfunction as a cause of ageing. Journal of Internal Medicine 263 167-178. (https://doi org/10.1111/j.1365-2796.2007.01905.x)
Twig G, Elorza A, Molina AJ, Mohamed H, Wikstrom JD, Walzer G, Stiles L, Haigh SE, Katz S, Las G, et al. 2008 Fission and selective fusion govern mitochondrial segregation and elimination by autophagy. EMBO Journal 27 433-446. (https://doi.org/10.1038/ sj.emboj.7601963)

Vimaleswaran KS, Radha V, Ghosh S, Majumder PP, Deepa R, Babu HNS, Rao MRS \& Mohan V 2005 Peroxisome proliferator-activated receptorgamma co-activator-1 alpha (PGC-1 alpha) gene polymorphisms and their relationship to Type 2 diabetes in Asian Indians. Diabetic Medicine 22 1516-1521. (https://doi.org/10.1111/j.14645491.2005.01709.x)

Wiederkehr A \& Wollheim CB 2012 Mitochondrial signals drive insulin secretion in the pancreatic beta-cell. Molecular and Cellular Endocrinology 353 128-137. (https://doi.org/10.1016/j. mce.2011.07.016)

Wikström JD, Katzman SM, Mohamed H, Twig G, Graf SA, Heart E, Molina AJ, Corkey BE, de Vargas LM, Danial NN, et al. 2007 Beta-cell mitochondria exhibit membrane potential heterogeneity that can be altered by stimulatory or toxic fuel levels. Diabetes $\mathbf{5 6} 2569-2578$.

Wollheim CB 2000 Beta-cell mitochondria in the regulation of insulin secretion: a new culprit in type II diabetes. Diabetologia 43 265-277. (https://doi.org/10.1007/s001250050044)

Yoon JC, Xu G, Deeney JT, Yang SN, Rhee J, Puigserver P, Levens AR, Yang R, Zhang CY, Lowell BB, et al. 2003 Suppression of beta cell energy metabolism and insulin release by PGC-1alpha. Developmental Cell 5 73-83. (https://doi.org/10.1016/S15345807(03)00170-9)

Zeggini E, Weedon MN, Lindgren CM, Frayling TM, Elliott KS, Lango H, Timpson NJ, Perry JR, Rayner NW, Freathy RM, et al. 2007 Replication of genome-wide association signals in UK samples reveals risk loci for type 2 diabetes. Science 316 1336-1341. (https://doi.org/10.1126/ science.1142364)

Zhang Y \& Chan DC 2007 Structural basis for recruitment of mitochondrial fission complexes by Fis1. PNAS 104 18526-18530. (https://doi.org/10.1073/pnas.0706441104)

Zhang J \& Ney PA 2009 Role of BNIP3 and NIX in cell death, autophagy, and mitophagy. Cell Death and Differentiation 16 939-946. (https:// doi.org/10.1038/cdd.2009.16)

Zhang CY, Baffy G, Perret P, Krauss S, Peroni O, Grujic D, Hagen T, VidalPuig AJ, Boss O, Kim YB, et al. 2001 Uncoupling protein-2 negatively regulates insulin secretion and is a major link between obesity, beta cell dysfunction, and type 2 diabetes. Cell 105 745-755. (https://doi. org/10.1016/S0092-8674(01)00378-6)

Zhang ZY, Wakabayashi N, Wakabayashi J, Tamura Y, Song WJ, Sereda S, Clerc P, Polster BM, Aja SM, Pletnikov MV, et al. 2011 The dynamin-related GTPase Opa1 is required for glucose-stimulated ATP production in pancreatic beta cells. Molecular Biology of the Cell 22 2235-2245. (https://doi.org/10.1091/mbc.E10-12-0933)

Received in final form 7 December 2017

Accepted 15 January 2018 http://joe.endocrinology-journals.org

https://doi.org/10.1530/JOE-17-0367
() 2018 Society for Endocrinology Published by Bioscientifica Ltd. Printed in Great Britain 